\title{
Potensi Penyakit Tular Vektor di Kabupaten Pangkajene dan Kepulauan, Propinsi Sulawesi Selatan
}

\author{
POTENTIAL VECTOR BORNE DISEASES IN PANGKAJENE AND ISLAND REGENCIES \\ OF SOUTH SULAWESI PROVINCE
}

\author{
Riyani Setiyaningsih ${ }^{1}$, Widiarti ${ }^{1}$, Mega Tyas Prihatin ${ }^{1}$, Nelfita ${ }^{2}$, Yusnita Mirna Anggraeni ${ }^{1}$, \\ Siti Alfiah ${ }^{1}$, Joy V I Sambuaga ${ }^{3}$,Tri Wibowo Ambargarjito ${ }^{1}$ \\ ${ }^{1}$ Balai Besar Penelitian dan Pengembangan Vektor dan Reservoir Penyakit \\ ${ }^{2}$ Balai Litbang Donggala ${ }^{3}$ Poltekes Kemenkes Menado Indonesia \\ E - mail : riyanisetia@gmail.com
}

Submitted : 2-07-2018, Revised : 28-08-2018, Revised:17-09-2018, Accepted : 5-12-2018

\begin{abstract}
Cases of malaria, dengue fever, chikungunya, filariasis, and Japanese encephalitis are still found in South Sulawesi. For instance, malaria, dengue hemorrhagic fever and filariasis remain endemic in Pangkajene Regency and Islands Regencies. The existence of these vectors will affect the transmission of potential vector-borne diseases. The purpose of this research is to determine the potential transmission of those diseases including Japanese encephalitis in those areas. Data were collected by catching adult mosquitoes and larvae in forest, non-forest and coastal ecosystems according to the WHO methods, including human man landing collection, animal baited trap net, animal feed, resting morning, and light trap. The larva survey was conducted at the mosquito breeding place. Pathogens in mosquitoes were detected in a laboratory using Polimerase Chain Reaction. The study found plasmodium in some species. They were Anopheles vagus in a residential ecosystem near settlement, Anopheles subpictus in forest ecosystems near settlements and non forest remote settlements, Anopheles barbirostris was found near and remote forest ecosystems, Anopheles indifinitus found in nearby forest ecosystems and nonforest close to settlements. Moreover, Culex tritaeniorhynchus containing japanese encephalitis virus was found in the non-forested residential ecosystem. However, mosquito samples with dengue fever virus, chikungunya and filariasis were not found.
\end{abstract}

Keywords: malaria,DHF, chikungunya, filariasis, Japanese encephalitis

\begin{abstract}
Abstrak
Kasus malaria, demam berdarah, chikungunya, filariasis dan Japanese encephalitis masih ditemukan di Sulawesi Selatan Sebagai contoh, Kabupaten Pangkajene dan Kepulauan merupakan salah satu kabupaten yang masih endemis malaria, demam berdarah dengue, dan filariasis. Keberadaan vektor akan mempengaruhi potensi penularan penyakit tular vektor. Tujuan penelitian adalah mengetahui potensi penularan malaria, demam berdarah, chikungunya, filarisis dan Japanese encephalitis di Kabupaten Pangkajene dan Kepulauan. Pengumpulan data dilakukan dengan cara enangkapan nyamuk dewasa dan jentik di ekosistem hutan, non hutan dan pantai. Metode penangkapan nyamuk dewasa dan jentik mengacu pada standart WHO yang meliputi human man landing collection, animal baited trap net, umpan ternak, resting pagi, dan light trap. Survei jentik dilakukan di tempat perkembangbiakan nyamuk. Nyamuk di deteksi patogennya di laboratorium dengan menggunakan Polimerase Chain Reaction. Hasil menunjukkan bahwa yang positif Plasmodium adalah Anopheles vagus di ekosistem hutan dekat pemukiman, Anopheles subpictus di ekosistem hutan dekat pemukiman dan non hutan jauh pemukiman, Anopheles barbirostris di ekosistem hutan dekat dan jauh pemukiman, Anopheles indefinitus di ekosistem hutan dekat pemukiman dan non hutan dekat pemukiman. Culex tritaeniorhynchus positif virus Japanese encephalitis di ekosistem non hutan jauh pemukiman. Namun idak ditemukan sampel nyamuk yang positif virus demam berdarah dengue, chikungunya, dan filariasis.
\end{abstract}

Kata kunci: malaria, DBD, chikungunya, filariasis, japanese encephalitis 


\section{PENDAHULUAN}

Sulawesi Selatan merupakan propinsi yang masih endemis beberapa penyakit tular vektor antara lain malaria, demam berdarah dengue (DBD), chikungunya, filariasis, dan Japanese Encephalitis. Salah satu kabupaten yang endemis penyakit tular vektor di propinsi itu adalah Kabupaten Pangkajene dan Kepulauan. Di Kabupaten Pangkajene dan Kepulauan kasus malaria pada tahun 2015 ditemukan 82 kasus dan tahun 2016 ada 62 kasus. Kasus DBD pada tahun 2015 ada 379 kasus dan tahun 2016 meningkat menjadi 911 kasus. Pada tahun 2016 ditemukan kasus filariasis 20 kasus. Di Kabupaten Pangkajene dan Kepulauan belum pernah dilaporkan adanya kasus Japanese Encephalitis. Pada tahun 2016 di Sulawesi Selatan masih ditemukan 24 kabupaten/ kota yang masih endemis malaria. Daerah yang telah mencapai eliminasi baru kurang lebih 58\% 1,2

Beberapa faktor yang mendukung suatu daerah berpotensi terjadi penularan penyakit tular vektor khususnya nyamuk antara lain adalah perilaku vektor dan manusia serta keberadaan lingkungan yang mendukung tempat perkembangbiakan vektor., ${ }^{3,4}$ Berdasarkan data sebelumnya vektor malaria di Sulawesi Selatan adalah Anopheles nigerrimus, Anopheles sundaicus, Anopheles barbirostris, Anopheles flavirostris, Anopheles ludlowae dan Anopheles subpictus. Vektor filariasis yang ditemukan adalah Anopheles barbirostris, Mansonia dives, Mansonia uniformis, dan Mansonia annulifera. Vektor DBD dan chikungunya adalah Aedes aegypti dan Aedes albopictus. Belum pernah dilaporkan adanya vektor JE di Kabupaten Pangkajene dan Kepulauan. ${ }^{6,7}$

Keberadaan vektor kemungkinan berbeda menurut variasi ekosistem. Eksosistem dibagi menjadi tiga yaitu eksosistem hutan, non hutan dan pantai. Keberadaan vektor dan agen patogen di suatu ekosistem dapat berpotensi terjadinya penularan penyakit tular vektor. ${ }^{6}$

Kabupaten Pangkajene dan Kepulauan merupakan salah satu kabupaten yang memiliki ekosistem hutan, non hutan dan pantai. Belum banyak dilaporkan data tentang vektor malaria. DBD, chikungunya, filariasis, dan Japanese enchephalitis di berbagai variasi ekosistem di
Kabupaten Pangkajene dan Kepulauan serta potensi terjadinya penularan penyakit tular vektor. Penelitian ini bertujuan untuk mengetahui potensi terjadinya penularan penyakit tular vektor serta vektor yang berperan di Kabupaten Pangkajene dan Kepulauan Sulawesi Selatan.

\section{BAHAN DAN CARA}

Penelitian ini dilakukan pada bulan Mei 2017. Sampel yang diambi adalah semua spesies nyamuk dan jentik dari genus Anopheles, Culex, Armigeres, Aedes dan Mansonia yang tertangkap di lapangan. Pengambilan sampel dilakukan di Kabupaten Pangkajene dan Kepulauan di enam titik di tiga ekosistem. Ke enam titik pengambilan sampel adalah ekosistem hutan dekat pemukiman (HDP), hutan jauh pemukiman (HJP), non hutan dekat pemukiman (NHDP), non hutan jauh pemukiman (NHJP), pantai dekat pemukiman (PDP), dan pantai jauh pemukiman (PJP). Pengambilan sampel pada ekosistem HDP dan HJP dilakukan di Kecamatan Segeri Desa Baring. Pada ekosistem NHDP dilakukan di Kecamatan Lebakkang Desa Patallasang. Pada ekosistem NHJP dilakukan di Kecamatan Marang, Desa Alesipitto. Pada ekosistem PDP dilakukan Kecamatan Segeri Desa Bawasalo Sedangkan pada ekosistem PJP dilakukan di Kecamatan Pangkajene Desa Tecolabbua. Pada masing-masing ekosistem dilakukan Penangkapan nyamuk dan jentik yang mengacu pada standart WHO dan buku pedoman pengumpulan data vektor di lapangan. ${ }^{6,8}$

Penangkapan nyamuk dilakukan dengan menggunakan metode human man landing colection di dalam dan luar rumah, umpan ternak (UT), Animal Baited Trap net (ABT), light trap, dan penangkapan nyamuk resting morning. Pada setiap titik penangkapan di setiap ekosistem dilakukan penangkapan nyamuk sebanyak dua kali dengan menggunakan metode human man landing colection, ABT, UT dan light trap. Penangkapan nyamuk dengan human man landing collection, ABT, light trap dan UT dilakukan pada pukul 18.00 sampai 06.00 . Besok harinya sampel yang dibagi menjadi dua yaitu $20 \%$ untuk spesimen dan $80 \%$ digunakan untuk deteksi patogen dengan menggunakan PCR. 8,6

Pemeriksaan Plasmodium dilakukan pada spesies yang masuk genus Anopheles. Pada 
deteksi Plasmodium primer yang digunakan adalah rPLU1 (TCA AAG ATT AAG CCA TGC AAG TGA), rPLU5 (CCT GTT GTT GCC TTA AAC TCC), rPLU3 (TTT TTA TAA GGA TAA CTA CTA CGG AAA AGC TGT), rPLU4 (TAC CCG TCA TAG CCA TGT TAG GCC AAT ACC). PCR dilakukan dalam dua tahap. Tahap pertama menggunakan primer PLU1 dan PLU5. Sedangkan tahap kedua menggunakan PLU3 dan PLU4. Pemeriksaan DBD dan chikungunya dilakukan pada spesies yang masuk dalam genus Aedes. Primer yang digunakan dalam pemeriksaan virus dengue adalah D1 ( TCA ATA TGC TGA AAC GCG CGA GAA ACC G) dan D2 (TTG CAC CAA CAG TCA ATG TCT TCA GGT TC). Sedangkan primer deteksi chikungunya yang digunakan adalah Chik 1 (ACC GGC GTC TAC CCA TTC ATG T) dan chik 2 (GGG CGG GTA GTC CAT GTT GTA GA). Pemeriksaan cacing filaria dan JE dilakukan pada spesies nyamuk hasil penagkapan dari genus Culex, Armigeres dan Mansonia. Deteksi JE primer reverse yang digunakan adalah TTT CAC GCT CTT TCT ACA GT sedangkan primer forward adalah AGA GCG GGG AAA AAG GTC AT. Deteksi cacing filaria dilakukan untuk deteksi Wuchereria bancrofti dan Brugia spp. Primer yang digunakan untuk deteksi $W$. bancrofti adalah NV-1 (CGT GAT GGC ATC AAA GTA GGG) dan NV-2 (CCC TCA CTT ACC ATA AGA CAA C) ${ }^{6,9}$

Survei jentik dilakukan di tempat-tempat yang berpotensi sebagai tempat perkembangbiakan vektor malaria, DBD, chikungunya, filariasis dan JE. Survei dilakukan baik di daerah pemukiman maupun non pemukiman. Jentik yang terkoleksi kemudian dipelihara sampai menjadi dewasa kemudian diidentifikasi spesiesnya., ${ }^{6,10-12}$ Data penelitian ini merupakan data sebagian hasil Riset Khusus Vektor dan Reservoir Penyakit tahun 2017 yang telah memperoleh persetujuan dari komisi etik no LB.02.01/5.2/KE.020/2017 dan telah meminta ijin pada Manjemen Data.

\section{HASIL}

Berdasarkan hasil penangkapan nyamuk dengan berbagai metode diperoleh Aevexans, An.barbirostris, An. indefinitus, An.subpictus, An. vagus dan $C x$.tritaeniorhynchus baik pada metode UOD, UOL, ABT, UT dan resting morning. Akan tetapi persebaran masing-masing spesies dari genus Aedes, Anopheles Culex, dan Mansonia berbeda pada setiap metode penangkapan dan eksositem.

Penangkapan nyamuk berdasarkan metode penangkapan UOD dari genus Aedes diperoleh Ae. aegypti, Ae. albopictus dan Ae.vexans. Beberapa spesies Anopheles yang ditemukan adalah An.barbirostris An.indefinitus, An.subpictus, An.tesselatus, An.vagus dan An.peditaeniatus. Dari genus Culex diperoleh Cx.fuscocephalus, Cx.annulirostris, Cx.whitei, Cx.infula, Cx.sitiens, Cx.annulus, Cx.gelidus, Cx.tritaeniorhynchus, Cx.vishnui dan Cx.quinquefasciatus. Sedangkan dari genus Mansonia hanya ditemukan Mn uniformis. Distribusi nyamuk yang tertangkap pada masing-masing ekosistem dapat dilihat pada Tabel 1.

Hasil penangkapan nyamuk dengan metode UOL spesies Aedes yang ditemukan sama dengan pada metode UOD. Spesies Anopheles yang ditemukan adalah $A n$. peditaeniatus, An .kochi, An. sulawesi, An. peditaeniatus, Anvvagus, An. indefinitus, An.barbirostris, dan An.subpictus. Pada genus Culex ditemukan Cx. infula, Cx.bitaeniorhynchus, Cx.quinquefasciatus, Cx.annulus, Cx.tritaeniorhynchus, CX.vishnui, $C x$. gelidus, Cx.whitei, dan Cx.sitiens. Pada metode ini genus Mansonia yang ditemukan hanya Mn. uniformis (Tabel 2).

Hasil survei dengan ABT diperoleh Ae. scanloni, Ae. albopictus dan Ae. vexans. Beberapa spesies Anopheles yang tertangkap adalah $A n$. ludlowae An. kochi, An. tesselatus, An. vagus, An. peditaeniatus, dan An. indefinitus, An. barbirostris, dan An. subpictus. Genus Culex yang tertangkap adalah $C x$. annulirostris, $C x$. nigropunctatus ,Cx. sinensis, $C x$. quinquefasciatus, $C x$. infula, $C x$. annulus, Cx.vishnui, $C x$. gelidus, $C x$. sitiens, $C x$. tritaeniorhynchus, $C x$ bitaeniorhynchus dan $C x$. whitei. Mansonia uniformis juga ditemukan pada metode penagkapan ini. Persebaran masingmasing spesies dapat dilihat pada Tabel 3.

Berdasarkan penangkapan nyamuk dengan metode UT tertangkap Ae.vexans, An.subpictus, An.barbirostris, An. indefinitus, An. peditaeniatus, An. vagus, Cx. annulus, Cx.gelidus, Cx.tritaeniorhynchus, Cx.vishnui, Cx.sitiens, Cx.whitei, Cx. quinquefasciatus, dan Cx.bitaeniorhynchus. Distribusi masing-masing 
spesies pada tiap ekosistem dapat dilihat pada Tabel 4.

Hasil penangkapan nyamuk istirahat pagi hari ditemukan Ae. aegypti, Ae. albopictus, Ae. gardnerii, Ae. vexans, An. barbirostris, An. indefinitus, serta An. subpictus. Beberapa genus Culex yang ditemukan antara lain Cx.gelidus, Cx. tritaeniorhynchus, Cx. vishnui, Cx.annulus, $C x$. quinquefasciatus, $C x$. whitei, Cx. foliatus dan Cx.sinensis. Mansonia uniformis juga ditemukan di penangkapan pagi hari. Distribusi semua spesies ini dapat dilihat pada Tabel 5. Hasil penangkapan dengan menggunakan light trap tidak diperoleh nyamuk .

Berdasarkan deteksi patogen An. vagus, An. subpictus, An. barbirostris dan An. indefinitus positif Plasmodium falcifarum di Kabupaten Pangkajenene dan Kepulauan. Cx tritaeniorhyncus juga terbukti positif mengandung virus Japanese encephalitis. Penyebaran spesies yang positif $P$. falcifarum dan virus JE di berbagai ekosistem dapat dilihat pada Tabel 6. An. vagus dan $A n$. indefiniitus yang positif $P$. falciparum ditemukan menghisap darah hewan sedangkan An. subpictus dan An. barbirostris menghisap darah hewan dan manusia. $C x$. tritaeniorhynchus yang positif virus JE juga menghisap darah hewan.

Hasil survei jentik ditemukan beberapa tempat perkembangbiakan nyamuk vektor pada beberapa ekosistem. Pada ekosistem PJP di tambak ditemukan jentik An. subpictus. $C x$. tritaeniorhynchus ditemukan di rawa air tawar pada ekosistem PDP. Sedangkan di ekosistem NHDP terdapat beberapa habitat spesifik yang ditemukan yaitu rawa air tawar, sawah dan parit. $C x$. tritaeniorhynchus dan An. peditaeniatus ditemukan pada air tawar, sedangkan pada parit diperoleh An. barbirostris.

Tabel 1. Distribusi Nyamuk Genus Anopheles, Aedes, Culex dan Mansonia pada Berbagai Ekosistem yang Tertangkap dengan Metode Umpan Dalam (UOD) di Kabupaten Pangkajene dan Kepulauan Sulawesi Selatan Tahun 2017

\begin{tabular}{|c|c|c|c|c|c|c|c|c|}
\hline \multirow[t]{2}{*}{ Genus } & \multirow{2}{*}{\multicolumn{2}{|c|}{ Spesies }} & \multicolumn{6}{|c|}{ Ekosistem } \\
\hline & & & HDP & HJP & NHDP & NHJP & PDP & PJP \\
\hline & & & - & - & $-\quad-$ & - & - & - \\
\hline \multirow[t]{3}{*}{ Aedes } & 1 & Aedes aegypti & - & - & - & - & 24 & - \\
\hline & 2 & Aedes albopictus & - & - & 2 & - & 1 & - \\
\hline & 3 & Aedes vexans & 26 & - & 10 & - & - & - \\
\hline \multirow[t]{6}{*}{ Anopheles } & 1 & Anopheles barbirostris & 3 & - & 16 & - & - & - \\
\hline & 2 & Anopheles indefinitus & & - & 7 & - & - & - \\
\hline & 3 & Anopheles subpictus & 1 & - & 13 & - & - & - \\
\hline & 4 & Anopheles tesselatus & 1 & - & 1 & - & - & - \\
\hline & 5 & Anopheles vagus & 3 & - & 6 & - & - & - \\
\hline & 6 & Anopheles peditaeniatus & 1 & - & - & - & - & - \\
\hline \multirow[t]{10}{*}{ Culex } & 1 & Culex fuscocephalus & 1 & - & - & - & - & - \\
\hline & 2 & Culex annulirostris & 1 & - & - & - & - & - \\
\hline & 3 & Culex quinquefasciatus & 73 & - & 11 & - & 69 & - \\
\hline & 4 & Culex whitei & 5 & - & - & - & 10 & - \\
\hline & 5 & Culex annulus & 195 & - & 45 & - & - & - \\
\hline & 6 & Culex gelidus & 19 & - & 3 & - & - & - \\
\hline & 7 & Culex infula & & - & 2 & - & - & - \\
\hline & 8 & Culex sitiens & & - & 14 & - & - & - \\
\hline & 9 & Culex tritaeniorhynchus & 206 & - & 39 & - & - & - \\
\hline & 10 & Culex vishnui & 31 & - & 35 & - & - & - \\
\hline Mansonia & 1 & Mansonia uniformis & 1 & - & 4 & - & 3 & - \\
\hline
\end{tabular}

Keterangan:

HDP : Hutan Dekat Pemukiman

HJP : Hutan Jauh Pemukiman

NHDP : $\quad$ Non Hutan Dekat Pemukiman

NHJP : $\quad$ Non Hutan Jauh Pemukiman

PDP : Pantai Dekat Pemukiman

PJP : Pantai Jauh Pemukiman 
Tabel 2. Distribusi Nyamuk Genus Anopheles, Aedes, Culex dan Mansonia pada Berbagai Ekosistem yang Tertangkap dengan Metode Umpan Orang Luar (UOL) di Kabupaten Pangkajene dan Kepulauan Sulawesi Selatan Tahun 2017

\begin{tabular}{|c|c|c|c|c|c|c|c|c|}
\hline \multirow[t]{2}{*}{ Genus } & \multirow[t]{2}{*}{ Spesies } & & \multicolumn{6}{|c|}{ Ekosistem } \\
\hline & & & HDP & HJP & NHDP & NHJP & PDP & PJP \\
\hline \multirow[t]{3}{*}{ Aedes } & 1 & Aedes aegypti & 3 & 1 & - & - & 5 & - \\
\hline & 2 & Aedes vexans & 61 & 37 & 16 & 66 & - & - \\
\hline & 3 & Aedes albopictus & 1 & - & - & - & - & - \\
\hline \multirow[t]{8}{*}{ Anopheles } & 1 & Anopheles barbirostris & 11 & 28 & 15 & 31 & 1 & 1 \\
\hline & 2 & Anopheles subpictus & 6 & 9 & 26 & 24 & 7 & 71 \\
\hline & 3 & Anopheles indefinitus & 4 & 6 & 1 & 8 & - & 5 \\
\hline & 4 & Anopheles nigerrimus & - & - & - & - & - & 2 \\
\hline & 5 & Anopheles peditaeniatus & 3 & - & - & 4 & - & 1 \\
\hline & 6 & Anopheles vagus & 10 & 2 & 6 & 14 & - & - \\
\hline & 7 & Anopheles kochi & - & 1 & - & - & - & - \\
\hline & 8 & Anopheles sulawesi & - & 1 & - & - & - & - \\
\hline \multirow[t]{10}{*}{ Culex } & 1 & Culex quinquefasciatus & 62 & - & 11 & - & 57 & - \\
\hline & 2 & Culex whitei & 32 & 52 & 1 & 52 & 9 & - \\
\hline & 3 & Culex sitiens & 2 & 10 & 35 & 51 & - & 144 \\
\hline & 4 & Culex annulus & 811 & 1.145 & 86 & 824 & - & - \\
\hline & 5 & Culex bitaeniorhynchus & - & 3 & - & 4 & - & - \\
\hline & 6 & Culex gelidus & 32 & 98 & 6 & 90 & - & - \\
\hline & 7 & Culex infula & - & - & - & 51 & - & - \\
\hline & 8 & Culex sinensis & 2 & 3 & & 11 & - & - \\
\hline & 9 & Culex tritaeniorhynchus & 419 & 73 & 47 & 78 & - & - \\
\hline & 10 & Culex vishnui & 65 & 142 & 69 & 198 & - & - \\
\hline Mansonia & 1 & Mansonia uniformis & 4 & 1 & 2 & 12 & & 15 \\
\hline
\end{tabular}

Keterangan:
HDP : Hutan Dekat Pemukiman
NHJP : Non Hutan Jauh Pemukiman
HJP : Hutan Jauh Pemukiman
PDP : Pantai Dekat Pemukiman
NHDP : Non Hutan Dekat Pemukiman
PJP : Pantai Jauh Pemukiman

Tabel 3. Distribusi Nyamuk Genus Anopheles, Aedes, Culex dan Mansonia pada Berbagai Ekosistem yang Tertangkap dengan Metode Animal Bited Trap (ABT) di Kabupaten Pangkajene dan Kepulauan Sulawesi Selatan tahun 2017

\begin{tabular}{|c|c|c|c|c|c|c|c|c|}
\hline \multirow[t]{2}{*}{ Genus } & \multirow[t]{2}{*}{ Spesies } & & \multicolumn{6}{|c|}{ Ekosistem } \\
\hline & & & HDP & HJP & NHDP & NHJP & PDP & PJP \\
\hline \multirow[t]{3}{*}{ Aedes } & 1 & Aedes (petermattinglya) scanloni & - & - & - & - & 1 & - \\
\hline & 2 & Aedes albopictus & - & - & - & - & 1 & - \\
\hline & 3 & Aedes vexans & 108 & - & 124 & 413 & - & - \\
\hline \multirow[t]{8}{*}{ Anopheles } & 1 & Anopheles barbirostris & 45 & - & 92 & 17 & 17 & - \\
\hline & 2 & Anopheles subpictus & 58 & - & 305 & 79 & 4 & - \\
\hline & 3 & Anopheles indefinitus & 64 & - & 133 & 160 & - & - \\
\hline & 4 & Anopheles Iudlowae & - & - & - & 3 & - & - \\
\hline & 5 & Anopheles peditaeniatus & 27 & - & 5 & 36 & - & - \\
\hline & 6 & Anopheles tesselatus & 3 & - & - & 1 & - & - \\
\hline & 7 & Anopheles vagus & 332 & - & 150 & 199 & - & - \\
\hline & 8 & Anopheles kochi & 1 & - & 1 & - & - & - \\
\hline \multirow[t]{13}{*}{ Culex } & 1 & Culex bitaeniorhynchus & 1 & & & 4 & 2 & - \\
\hline & 2 & Culex gelidus & 158 & - & 17 & 58 & 4 & - \\
\hline & 3 & Culex quinquefasciatus & & - & - & & 24 & - \\
\hline & 4 & Culex sitiens & 7 & - & 12 & 10 & 19 & - \\
\hline & 5 & Culex sp & 1 & - & - & & 1 & - \\
\hline & 6 & Culex tritaeniorhynchus & 390 & - & 131 & 226 & 9 & - \\
\hline & 7 & Culex whitei & 14 & - & - & 7 & 155 & - \\
\hline & 8 & Culex annulus & 29 & - & 30 & 141 & - & - \\
\hline & 9 & Culex infula & & - & 2 & 15 & - & - \\
\hline & 10 & Culex vishnui & 6 & - & 23 & 27 & - & - \\
\hline & 11 & Culex annulirostris & 1 & - & - & - & - & - \\
\hline & 12 & Culex nigropunctatus & 1 & - & - & - & - & - \\
\hline & 13 & Culex sinensis & 1 & - & - & - & - & - \\
\hline Mansonia & 1 & Mansonia uniformis & - & - & 2 & 1 & 7 & - \\
\hline
\end{tabular}

Keterangan:

HDP : Hutan Dekat Pemukiman

HJP : Hutan Jauh Pemukiman

NHDP : Non Hutan Dekat Pemukiman
NHJP : Non Hutan Jauh Pemukiman

PDP : Pantai Dekat Pemukiman

PJP : Pantai Jauh Pemukiman 
Tabel 4. Distribusi Nyamuk Genus Anopheles, Aedes, Culex dan Mansonia pada Berbagai Ekosistem yang Tertangkap dengan Metode Umpan Ternak (UT) di Kabupaten Pangkajene dan Kepulauan Sulawesi Selatan tahun 2017

\begin{tabular}{|c|c|c|c|c|c|c|c|}
\hline \multirow[t]{2}{*}{ Genus } & \multirow[t]{2}{*}{ Spesies } & \multicolumn{6}{|c|}{ Ekosistem } \\
\hline & & HDP & HJP & NHDP & NHJP & PDP & PJP \\
\hline Aedes & Aedes vexans & 31 & - & 89 & - & - & - \\
\hline \multirow[t]{5}{*}{ Anopheles } & 1 Anopheles subpictus & 16 & - & 169 & - & 24 & - \\
\hline & 2 Anopheles barbirostris & 3 & - & 16 & - & - & - \\
\hline & 3 Anopheles indefinitus & 11 & - & 48 & - & - & - \\
\hline & 4 Anopheles peditaeniatus & 1 & - & 3 & - & - & - \\
\hline & 5 Anopheles vagus & 27 & - & 53 & - & - & - \\
\hline \multirow[t]{8}{*}{ Culex } & 1 Culex bitaeniorhynchus & - & - & - & - & 1 & - \\
\hline & 2 Culex quinquefasciatus & - & - & 3 & - & 56 & - \\
\hline & 3 Culex sitiens & 2 & - & 8 & - & 4 & - \\
\hline & 4 Culex whitei & 19 & - & - & - & 4 & - \\
\hline & 5 Culex annulus & 34 & - & 51 & - & - & - \\
\hline & 6 Culex gelidus & 85 & - & 18 & - & - & - \\
\hline & 7 Culex tritaeniorhynchus & 501 & - & 74 & - & - & - \\
\hline & 8 Culex vishnui & 6 & - & 38 & - & - & - \\
\hline
\end{tabular}

Keterangan:
HDP : Hutan Dekat Pemukiman
NHJP : Non Hutan Jauh Pemukiman
HJP : Hutan Jauh Pemukiman
PDP : Pantai Dekat Pemukiman
NHDP : Non Hutan Dekat Pemukiman
PJP : Pantai Jauh Pemukiman

Tabel 5. Distribusi Nyamuk Genus Anopheles, Aedes, Culex dan Mansonia pada Berbagai Ekosistem yang Tertangkap dengan Metode Resting Morning (RM) di Kabupaten Pangkajene dan Kepulauan Sulawesi Selatan Tahun 2017

\begin{tabular}{|c|c|c|c|c|c|c|c|}
\hline \multirow[t]{2}{*}{ Genus } & \multirow[t]{2}{*}{ Spesies } & \multicolumn{6}{|c|}{ Ekosistem } \\
\hline & & HDP & HJP & NHDP & NHJP & PDP & PJP \\
\hline \multirow[t]{4}{*}{ Aedes } & Aedes aegypti & 11 & - & 1 & - & - & - \\
\hline & Aedes albopictus & 1 & - & 3 & - & 15 & - \\
\hline & Aedes gardnerii & - & - & 4 & - & - & - \\
\hline & Aedes vexans & - & - & 15 & 3 & - & - \\
\hline \multirow[t]{4}{*}{ Anopheles } & Anopheles barbirostris & - & - & 4 & - & - & - \\
\hline & Anopheles indefinitus & 3 & - & - & - & - & - \\
\hline & Anopheles peditaeniatus & r & - & - & - & - & - \\
\hline & Anopheles subpictus & & - & 4 & - & - & 3 \\
\hline \multirow[t]{9}{*}{ Culex } & Culex annulus & 3 & - & 3 & 15 & - & - \\
\hline & Culex foliatus & 1 & - & - & - & - & - \\
\hline & Culex gelidus & 18 & 6 & 2 & 12 & 1 & 1 \\
\hline & Culex quinquefasciatus & 50 & - & 4 & - & 62 & \\
\hline & Culex sitiens & 1 & - & 2 & - & - & 12 \\
\hline & Culex tritaeniorhynchus & 39 & 2 & 6 & 2 & 1 & - \\
\hline & Culex vishnui & 3 & 1 & 8 & 12 & 1 & - \\
\hline & Culex whitei & - & - & - & 1 & 1 & - \\
\hline & Culex sinensis & - & - & 1 & - & - & - \\
\hline Mansonia & Mansonia uniformis & - & - & 3 & - & 3 & 1 \\
\hline
\end{tabular}

Keterangan:
HDP : Hutan Dekat Pemukiman
NHJP : Non Hutan Jauh Pemukiman
HJP : Hutan Jauh Pemukiman
PDP : Pantai Dekat Pemukiman
NHDP : Non Hutan Dekat Pemukiman
PJP : Pantai Jauh Pemukiman 
Tabel 6. Distribusi Nyamuk yang Terdeteksi Positif Plasmodium falciparum dan virus Japanese Encephalitis di Berbagai Ekosistem di Kabupaten Pangkajene dan Kepulauan Sulawesi Selatan 2017

\begin{tabular}{cccccccc}
\hline \multirow{2}{*}{ Agen patogen } & \multirow{2}{*}{ Spesies } & \multicolumn{9}{c}{ Ekosistem } \\
\cline { 3 - 7 } Malaria & An. vagus & HDP & HJP & NHDP & NHJP & PDP & PJP \\
& An. subpictus & + & - & - & - & - & - \\
& An. barbirostris & ++ & + & - & + & - & - \\
& An. indefinitus & + & - & + & - & - & - \\
& Cx. tritaeniorhynchus & & - & - & + & - & - \\
\hline
\end{tabular}

Keterangan:

$+\quad$ : sanpel positif Plasmodium

$+\quad \quad$ : sampel positif Plasmodium lebih dari satu pooling

- $\quad$ : sampel negatif

HDP : Hutan Dekat Pemukiman

HDP : Hutan Dekat Pemukiman

HJP : Hutan Jauh Pemukiman

NHDP : Non Hutan Dekat Pemukiman

NHJP : Non Hutan Jauh Pemukiman

PDP : Pantai Dekat Pemukiman

PJP : Pantai Jauh Pemukiman

\section{PEMBAHASAN}

Kabupaten Pangkajene dan Kepulauan merupakan kabupaten yang berpotensi terjadi penularan malaria baik di ekosistem HDP,HJP,NHDP dan NHJP. Hal ini disebabkan karena pada ekosistem tersebut masih ditemukan spesies Anopheles yang positif Plasmodium berdasarkan analisa PCR. Ekosistem HDP memiliki potensi yang lebih besar terjadi penularan malaria karena ditemukan empat spesies nyamuk positif Plasmodium yaitu An. vagus, An. subpictus, An. barbirostris dan An. indefinitus. Tingginya peluang terjadinya penularan malaria juga didukung oleh ditemukannya kasus malaria di Kabupaten Pangkajene dan Kepulauan. ${ }^{1}$

Berdasarkan studi sebelumnya Anopheles vagus juga dilaporkan sebagai vektor malaria di Jawa Tengah, dan NTT. An. subpictus merupakan vektor malaria di Jawa Tengah, Jawa Barat, Jawa Timur, Sulawesi Utara, Sulawesi Tenggara, NTT, dan Bengkulu. Sedangkan An. indifinitus sebelumnnya belum dilaporkan sebagai vektor malaria di Indonesia. ${ }^{6,13}$

Anopheles subpictus juga dilaporkan sebagai vektor malaria di Srilanka. Distribusi spesies ini cenderung ditemukan di daerah oriental. Beberapa daerah persebaran An. subpictus antara lain India, Afganistan, Pakistan, Iran, Papua Nugini, dan Pulau Marina. Tempat perkembangbiakan An. subpctus ditemukan air tawar maupun asin. An.subpictus juga diketahui sebagai vektor malaria di India.
Potensi An. subpictus sebagai vektor malaria sudah diketahui di Pulau Maldives, Sulawesi, Timor-timur dan Malaysia. ${ }^{14}$

Anopheles barbirostris di Indonesia sudah dilaporkan sebagai vektor di Sulawesi Selatan, Sulawesi Utara, Sulawesi Tengah, Sulawesi Tenggara, NTB dan NTT. An. barbirostris juga dilaporkan sebagai vektor malaria di Thailand. Kepadatan nyamuk terjadi pada musim hujan sampai kemarau. An. barbirostris berpotensi sebagai vektor karena banyak ditemukan di luar rumah. ${ }^{15}$

Perilaku nyamuk dapat berpengaruh terhadap potensinya sebagai vektor malaria. Secara umum nyamuk cenderung bersifat zoofilik akan tetapi kebanyakan bersifat antropozoofilik. Keduannya dapat berperan sebagai vektor. ${ }^{16} \mathrm{Hal}$ ini dapat dilihat dari hasil analisis di laboratorium An.subpictus ditemukan positif Plasmodium baik pada penangkapan umpan orang di luar rumah maupun animal baited trap. Demikian juga dengan An.barbirostris positif Plasmodium pada metode penangkapan umpan ternak dan umpan orang di luar rumah. Akan tetapi perilaku nyamuk menghisap darah manusia mempunyai peluang yang lebih besar untuk menjadi vektor karena terjadi kontak dengan manusia. ${ }^{17,18}$ Keberadaan ternak dekat pemukiman dapat meningkatkan risiko terjadinya penularan malaria. Berdasarkan penelitian di Kabupaten Pesawaran Propinsi Lampung menunjukkan bahwa penduduk yang memelihara ternak di dekat rumah memiliki risiko terkena malaria 10 kali jika dibandingkan penduduk yang tidak tinggal di dekat ternak. ${ }^{19}$

Potensi penularan malaria juga didukung oleh keberadaan tempat perkembangbiakan nyamuk vektor. Berdasarkan survei di Kabupaten Pangkajene dan Kepulauan ditemukan An. subpictus di tambak dan An.barbirostris di parit. Keberadaan tempat perkembangbiakan vektor adalah spesifik di tiap daerah. Jentik An. subpictus ditemukan di air bersih atau tempat perkembangbiakan yang ditutupi dengan alga atau seresah di Kecamatan Tanjung Bunga Flores Timur jentik. ${ }^{13}$ An. subpictus ditemukan di 
kubangan kerbau, parit, sawah dan saluran irigasi. An. subpictus juga bisa ditemukan di saluran air, kolam ikan, tempat bekas semen, saluran air di kebun, talang air, parit sumur, tepi danau dan sungai di Lombok. ${ }^{20}$ Jentik An. subpictus dan An. sundaicus terkadang dapat ditemukan pada satu habitat yang sama. An. subpictus memiliki toleransi terhadap kadar garam sehingga dapat ditemukan kadar garam yang yang rendah dan tinggi. ${ }^{21}$ An. vagus walaupun belum di temukan tempat perkembangbiakannya di Kabupaten Pangkajene dan Kepulauan tetapi mengingat berdasarkan hasil PCR bahwa nyamuk tersebut positif Plasmodium, maka tetap perlu diwaspadai potensinya sebagai vektor. Berdasarkan studi di Purworejo An. vagus ditemukan di sumber air, kobakan dan perit bersama dengan An. balabacensis dan An. kochi. Tempat perkembangbiakan yang disukai cenderung mengadung seresah dan tanaman air. $^{22}$

Berdasarkan data kasus di Kabupaten Pangkajene dan Kepulauan belum di temukan kasus JE. Dengan ditemukannnya Culex. tritaeniorhynchus positif virus JE di ekosistem NHJP maka perlu dilakukan tindakan kewaspadaan dini pengendalian vektor agar siklus penularan JE dapat dikendalikan. Faktor lain yang ikut berperan terhadap penularan JE adalah ditemukannya reservoirnya. Berdasarkan penelitian reservoir JE yang ditemukan antara lain babi dan burung. ${ }^{23,24}$ Berdasarkan studi sebelumnya An. quinquefasciatus, Culex bitaeniorhyncus, An.kochi, Armigeres subalbatus, dan $C x$. tritaeniorhynchus merupakan vektor JE di Jawa Tengah. $C x$. tritaeniorhynchus dan Cx. gelidus positif virus JE di Jawa Barat dan DKI Jakarta. Di Sumatera Utara nyamuk yang positif JE adalah $C x$. tritaeniorhynchus, $C x$. quinquefasciatus dan $C x$. fuscocephalus. ${ }^{6}$

Culex tritaeniorhynchus di Hokaido juga diketahui sebagai vektor JE dengan reservoirnya adalah burung air dan babi. Cx. tritaeniorhynchus cenderung menyukai darah babi ${ }^{25}$ Berdasarkan studi di Inggris Aedes detritus dan Cx. quinquefasciatus mampu menularkan virus JE. ${ }^{26}$ Hasil survei di Kabupaten Pangkajene dan Kepulauan tempat perkembangbiakan $C x$. tritaeniorhynchus ditemukan adalah sawah. Studi di Cina sebagai vektor JE $C x$. tritaeniorhynchus ditemukan di beberapa tempat perkembangbiakan saluran irigasi, tambak, tempat makan babi dan sawah. ${ }^{27}$ Beberapa spesies nyamuk lain yang ditemukan positif virus JE adalah $A e$. vexans, $C x$. medistus, $C x$. pipiens pallens, $C x$. pipiens quinquefasciatus, Cx. theileri, An. sinensis, Ar. subalbatus, dan Cx. fuscocephalus. ${ }^{27}$

Transmisi JE di suatu daerah dipengaruhi oleh beberapa faktor diantaranya suhu, kelembaban, cuaca dan presipitasi. Faktor lingkungan tersebut akan berpengaruh terhadap siklus hidup vektor dan kemampuan hidup patogen yang dapat ditularkan. Suhu yang meningkat dapat mempercepat proses replikasi patogen. Selain itu perubahan perilaku manusia yang berpotensi meningkatkan kontak dengan vektor akan mempercepat proses penularan $\mathrm{JE}^{28}$ Berdasarkan penelitian di Nepal terjadinya transmisi JE berhubungan dengan prosentase penggunaan lahan irigasi tetapi tidak berhubungan dengan curah hujan. ${ }^{29}$ Berdasarkan penelitian di Cina suhu dan curah hujan berpengaruh terhadap kepadatan nyamuk. Pada suhu 22-23 ${ }^{\circ} \mathrm{C}$ nyamuk dapat berkembang dengan maximum, sedangkan transmisi JE minimum terjadi pada suhu $25-26{ }^{\circ} \mathrm{C} .{ }^{28}$

Berdasarkan hasil uji laboratorium tidak ditemukan sampel yang positif virus DBD dan chikungunya di Kabupaten Pangkajene dan Kepulauan. Akan tetapi tetap perlu diwaspadai karena di kabupaten ini ditemukan vektor DBD dan chikungunya yaitu Ae. aegypti dan Ae. albopictus. ${ }^{6}$ Hasil pemeriksaan Ae. aegypti di Kabupaten Serdang Bedagai positif mengandung virus chikungunya di sekitar daerah penderita chikungunya. ${ }^{30}$ Di Kabupaten Banjarnegara pada Ae aegypti dan Ae. albopictus terbukti terjadi transovaria pada larva dengan menggunakan metode imunositokimia. ${ }^{31}$ Demikian juga di Kota Menado tansovaria virus DBD juga terjadi pada Ae. aegypti. ${ }^{32}$ Di luar negeri seperti Kuba dan Singapore Ae. aegypti juga merupakan vektor DBD yang terus digalakkan dalam proses pengendaliannya. ${ }^{33}$

Pada pemeriksaan filaria pada nyamuk di Kabupaten Pangkajene dan Kepulauan tidak ditemukan nyamuk yang positif filaria. Akan tetapi berdasarkan penangkapan nyamuk ditemukan beberapa spesiesyangberdasarkan studisebelumnnya diketahui sebagai vektor filariasis. Beberapa spesies yang ditemukan antara lain An barbirostris, dan Mn. uniformis. ${ }^{6}$ Terdapat variasi spesies vektor filariasis di wilayah Indonesia. An. barbirostris juga terkonfirmasi sebagai vektor filariasis di Kalimantan Selatan, Sulawesi Utara, Sulawesi Tengah, Sulawesi Tenggara dan NTT. ${ }^{6}$ Mn. uniformis juga merupakan vektor filariasis di Jawa Tengah, Lampung, Aceh, Sumatera Utara, Riau, Jambi, Sumatera Selatan, Kalimantan Barat, Kalimantan Tengah, Kalimantan Selatan, Kalimantan Timur, Sulawesi Selatan, Sulawesi Tengah, Maluku, Papua, dan Bengkulu. '34 Hasil studi di Jambi juga diketahui $C x$. quinquefasciatus berpotensi sebagai vektor filariasis pada deteksi cacing filaria B. malayi pada thorax dan probosis dengan menggunakan PCR. ${ }^{35} \mathrm{Di}$ 
Kecamatan Tanjung Jabung Timur Jambi Mansonia indiana ditemukan positif cacing Brugia malayi pada pemeriksaan dengan PCR. ${ }^{36}$ Di Pekalongan Jawa Tengah $C x$. quinquefasciatus terdeteksi positif Wuchereria bancrofti. ${ }^{37}$ Hasil penelitian di Gana ditemukan vektor filariasis W. brancofti adalah Mansonia africana dan Ma. uniformis. ${ }^{38}$ Di Nepal Cx. quinquefasciatus juga dilaporkan sebagai vektor filariasis. ${ }^{39}$

\section{KESIMPULAN}

Kabupaten Pangkajene dan Kepulauan masih berpotensi terjadi penularan penyakit tular vektor malaria dan JE . An. vagus, An. subpictus, An. barbirostris dan An. indifinitus ditemukan mengandung Plasmodium. Cx. tritaeniorhynchus terdeteksi virus Japanese encephalitis. DBD, chikungunya dan filariasis juga berpotensi terjadi penularan karena meskipun tidak ditemukan patogen pada nyamuk namun berdasarkan laporan sebelumnya dilaporkan Ae. aegypti dan Ae. albopictus sebagai vektor DBD dan chikungunya. An. barbirostris dan Mansonia uniformis dilaporkan sebagai vektor filariasis.

\section{UCAPAN TERIMA KASIH}

Dalam proses penulisan artikel ini tak lupa penulis mengucapkan terimksih kepada Kepala B2P2VRP Salatiga Bapak Joko Waluyo, BSc., ST., Dipl.EIA., MSc.PH dan Bapak DR Ristiyanto selaku penangung jawab Riset Khusus Vektora 2017. Dra Widiarti, M.Kes sebagai ketua PPI. Tak lupa kami juga mengucapkan banyak terimkasih kepada Kepala Balai Litbang Donggala, PJT Rikhus Vektora Propinsi Sulawesi Selatan, Tim Teknis Riset Kusus Vektora, Katim dan Wakatim Propinsi Sulawesi Selatan dan segenap tim pengumpul data Rikhus Vektora 2017.

\section{DAFTAR RUJUKAN}

1. Dinas Kesehatan Pangkajene dan Kepulauan. Profil Kesehatan Kabupaten Pangkajene dan Kepulauan 2016. Dinas Kesehatan kabupaten Pangkajene dan Kepulauan; 2016.

2. P2PTVZ. Situasi Terkini Perkembangan Program P engendalian Malaria di Indonesia Tahun 2016. Jakarta: P2PTVZ; 2016. 1-16 p.

3. Mayasari R, Andriyani D, Sitorus H. Faktor Risiko yang Berhubungan dengan Kejadian Malaria di Indonesia (Analisis Lanjut Riskesdas 2013 ). Bul Penelit Kesehat. 2016;44(1):13-24.
4. Bugoro H, Hii JL, Butafa C, Iro'Ofa C, Apairamo A, Cooper RD, et al. The Bionomics of The Malaria Vector Anopheles farauti in Northern Guadalcanal, Solomon Islands: Issues for successful vector control. Malar J. 2014;13(1):1-7.

5. Kementerian Kesehatan RI. Keputusan Menteri Kesehatan Republik Indonesia no293/Menkes/ SK/IV/2009. Jakarta; 2009. 1-36 p.

6. B2P2VRP. Pedoman Pengumpulan Data Vektor (Nyamuk) di Lapangan. Salatiga; 2017.

7. Nurdin A, Syafruddin D, Wahid I, Noor NN, Sunahara T, Mogi M. Malaria and Anopheles spp in The Villages of Salubarana and Kadaila , Mamuju District, South Sulawesi Province, Indonesia. Med J Indones. 2003;12(4):252-8.

8. WHO. Manual on Pactical Entomology in Malaria. Geneva; 1975. 1-186 p.

9. B2P2VRP. Pedoman Pemeriksaan Deteksi agen Penyakit. Salatiga; 2015.

10. Panthusiri, Rattanarithikul R, Prachong. Illustrated Keys to the Medically Important Mosquitoes of Thailand. Thailand; 1994. 1-66 p.

11. Rattanarithikul R, Harbach RE, Harrison BA, Panthusari P, Coleman RE, Richardson JH. Illustrated Keys to The Mosquitoes of Thailand VI. Tribe Aedini. Thailand; 2010. 1-128 p.

12. Rattanarithikul R, Harbach RE, Harrison BA, Panthusiri P, Jones JW, Coleman RE. Illustrated Keys to the mosquitoes of Thailand II Genera Culex and Lutzia. Thailand; 2005. 1-97 p.

13. Barodji, Sumardi, Suwaryono T, Rahardjo, Mujiono, Priyanto H. Berapa Aspek Bionomik Vektor Malaria dan Filariasis Anopheles subpictus Grassi di Kecamatan Tanjung Bunga, Flores Timur, NTT. Bul Penelit Kesehat. 2000;27(2).

14. Singh RK, Kumar G, Mittal PK, Dhiman RC. Bionomics and Vector Potential of Anopheles subpictus as a Malaria Vector in India: An overview. Int J Mosq Res. 2014;1(1):29-37.

15. Sriwichai P, Samung Y, Sumruayphol S, Kiattibutr K, Kumpitak C, Payakkapol A, et al. Natural Human Plasmodium Infections in Major Anopheles Mosquitoes in Western Thailand. Parasites and Vectors [Internet]. 2016;9(1):19. Available from: http://dx.doi.org/10.1186/ s13071-016-1295-x.

16. Elyazar IRF, Sinka ME, Gething PW, Tarmidzi SN, Surya A, Kusriastuti R, et al. The Distribution and Bionomics of Anopheles malaria Vector Mosquitoes in Indonesia. 1st ed. Vol. 83, Advances in Parasitology. Elsevier Ltd.; 2013. 173-266 p.

17. Keven JB, Reimer L, Katusele M, Koimbu 
G, Vinit R, Vincent N, et al. Plasticity of Host Selection by Malaria Vectors of Papua New Guinea. Parasit Vectors [Internet]. 2017;10(1):95. Available from: http://parasitesandvectors. biomedcentral.com/articles/10.1186/s13071017-2038-3.

18. Burkot TR, Russell TL, Reimer LJ, Bugoro H, Beebe NW, Cooper RD, et al. Barrier Screens: A Method to Sample Blood-fed and Host-Seeking Exophilic Mosquitoes. Malar J. 2013;12(1):1-9.

19. Idrus M, Gestrudis G. Hubungan Faktor Individu dan Lingkungan Rumah dengan Kejadian Malaria di Puskesmas Koeloda Kecamatan Golewa Kabupaten Ngada Provinsi NTT. J Kesehat [Internet]. 2014;VII(2):386-95. Available from: http://journal.uin-alauddin. ac.id/index.php/kesehatan/article/view/58.

20. Mading M, Kazwaini M. Ekologi Anopheles spp. di Kabupaten Lombok Tengah. ASPIRATOR - J Vector-borne Dis Stud. 2014;6(1):13-20.

21. RI DJP\& PDK. Vektor Malaria di Indonesia. 2007.

22. Lestari EW, Sukowati S, Soekidjo, Wigati R. Vektor malaria didaerah bukit menoreh, purworejo, jawa tengah. Media Litabng Kesehat XVII no 1 2007. 2007;1:30-5.

23. Sendow I, Bahri S. Perkembangan Japanese Encephalitis Di Indonesia. Wartazoa. 2005;15(3):2005.

24. Yun SI, Lee YM. Japanese encephalitis. Hum Vaccines Immunother. 2014;10(2):263-79.

25. Ricklin ME, García-Nicolás $\mathrm{O}$, Brechbühl D, Python S, Zumkehr B, Nougairede A, et al. Vector-free Transmission and Persistence of Japanese encephalitis Virus in Pigs. Nat Commun. 2016;7:1-9.

26. Mackenzie-Impoinvil L, Impoinvil DE, Galbraith SE, Dillon RJ, Ranson H, Johnson N, et al. Evaluation of a Temperate Climate Mosquito, Ochlerotatus detritus (=Aedes detritus), as a Potential Vector of Japanese encephalitis Virus. Med Vet Entomol. 2015;29(1):1-9.

27. Zheng Y, Li M, Wang H, Guodong Liang. Japanese encephalitis and Japanese encephalitis Virus in Mainland China. Rev Med Virol. 2012;25(1):1-22.

28. Tian HY, Bi P, Cazelles B, Zhou S, Huang SQ, Yang J, et al. How Environmental Conditions Impact Mosquito Ecology and Japanese encephalitis: An Eco-Epidemiological Approach. Environ Int [Internet]. 2015;79:1724. Available from: http://dx.doi.org/10.1016/j. envint.2015.03.002.

29. Impoinvil DE, Solomon T, Schluter WW, Rayamajhi A, Bichha RP, Shakya G, et al.
The Spatial Heterogeneity Between Japanese encephalitis Incidence Distribution and Environmental Variables in Nepal. PLoS One. 2011;6(7).

30. Panggbean YC, Kusumawati LR, Yulfi H. Deteksi Virus Chikungunya pada nyamuk Aedes aegypti di Kabupaten Serdang Bedagai. Maj Kedokt Nusant. 2014;47(1):14-8.

31. Pramestuti N, Widiastuti D, Raharjo J. Transmisi Transovari Virus Dengue pada Nyamuk Aedes aegypti dan Aedes albopictus di Kabupaten Banjarnegara. J Ekol Kesehat. 2013;12(3):18794.

32. Mosesa LP, Sorisi A, Pijoh VD. Deteksi Transmisi Transovarial Virus Dengue pada Aedes aegypti dengan Teknik Imunositokimia di Kota Manado. J e-Biomedik. 2016;4(1):116-21.

33. Achee NL, Gould F, Perkins TA, Reiner RC, Morrison AC, Ritchie S a., et al. A Critical Assessment of Vector Control for Dengue Prevention. PLoS Negl Trop Dis [Internet]. 2015;9(5):1-19. Available from: http://dx.doi. org/10.1371/journal.pntd.0003655.

34. Santoso S, Yahya Y, Salim M. Penentuan Jenis Nyamuk Mansonia sebagai Tersangka Vektor Filariasis Brugia malayi dan Hewan Zoonosis di Kabupaten Muaro Jambi. Media Litbangkes [Internet]. 2014;24 No 4:181-90. Available from: http://ejournal.litbang.depkes.go.id/index. $\mathrm{php} / \mathrm{MPK} / \mathrm{article} / \mathrm{view} / 3671$.

35. Yahya, Santoso, Salim M, Arisanti M. Deteksi Brugia malayi pada Armigeres subalbatus dan Culex quinquefasciatus yang Diinfeksikan Darah Penderita Filariasis dengan Metode PCR. Aspirator. 2014;6(September):35-42.

36. Santoso, Yahya, Suryaningtyas NH, Rahayu KS. Deteksi Mikrofilaria Brugia malayi pada Nyamuk Mansonia spp dengan Pembedahan dan Metode PCR di Kabupaten Tanjung Jabung Timur. Aspirator. 2015;7(April):29-35.

37. Febrianto B, Maharani, Astri, I P, Widiarti. Faktor Resiko Filariasis di Desa Samborejo, Kecamatan Tirto, Kabupaten Pekalongan Jawa Tengah. Bul Penelit Kesehat. 2008;36(2):48-58.

38. Ughasi J, Bekard HE, Coulibaly M, AdabieGomez D, Gyapong J, Appawu M, et al. Mansonia africana and Mansonia uniformis are Vectors in the Transmission of Wuchereria bancrofti lymphatic filariasis in Ghana. Parasites and Vectors. 2012;5(1):1-5.

39. Dhimal M, Gautam I, Kreß A, Müller R, Kuch U. Spatio-Temporal Distribution of Dengue and Lymphatic Filariasis Vectors along an Altitudinal Transect in Central Nepal. PLoS Negl Trop Dis. 2014;8(7):1-13. 